\title{
Biocontrol of Lettuce Drop Caused by Sclerotinia sclerotiorum and S. minor in Desert Agroecosystems
}

P. Chitrampalam, P. J. Figuli, and M. E. Matheron, Division of Plant Pathology and Microbiology, Department of Plant Sciences, University of Arizona, Tucson 85721; K. V. Subbarao, Department of Plant Pathology, University of California, Davis 95616; and B. M. Pryor, Division of Plant Pathology and Microbiology, Department of Plant Sciences, University of Arizona, Tucson 85721

\begin{abstract}
Chitrampalam, P., Figuli, P. J., Matheron, M. E., Subbarao, K. V., and Pryor, B. M. 2008. Biocontrol of lettuce drop caused by Sclerotinia sclerotiorum and S. minor in desert agroecosystems. Plant Dis. 92:1625-1634.

Field experiments were conducted over 2 years in Yuma County, AZ, and Imperial County, CA, to determine the efficacy of several biocontrol agents for the management of lettuce drop caused by Sclerotinia spp. Commercial formulations of Trichoderma harzianum (Plantshield, Supersivit), Gliocladium virens (Soilgard), Coniothyrium minitans (Contans), and Bacillus subtilis (Companion) were evaluated and compared with the chemical fungicide iprodione (Rovral) against Sclerotinia sclerotiorum and S. minor. A single application of biocontrol products or of Rovral did not reduce lettuce drop caused by either Sclerotinia species. However, two applications of Contans, one at planting and one at post-thinning, significantly reduced the incidence of lettuce drop caused by S. sclerotiorum and increased yield but had no effect on S. minor at both locations in both years. Two applications of other biocontrol products did not significantly reduce disease incidence despite medium to high recovery following application. In contrast, Contans was only sporadically recovered following application. In vitro fungicide sensitivity evaluation revealed that both Trichoderma and Gliocladium species were tolerant to iprodione, dicloran (Botran), and vinclozolin (Ronilan) up to 1,000 ppm a.i., whereas both Sclerotinia spp. and $C$. minitans were sensitive to all three fungicides above $1 \mathrm{ppm}$. In summary, Contans was the most effective treatment for the control of lettuce drop caused by $S$. sclerotiorum, but no treatment was effective against $S$. minor in the desert lettuce production systems.
\end{abstract}

Lettuce (Lactuca sativa L.) is one of the most widely consumed vegetables in the United States, and California and Arizona account for over $95 \%$ of U.S. production. Lettuce production occurs in three distinct regions within California, depending on the season, with one season coinciding with production in Arizona. Spring and summer production occurs in the Salinas Valley and coastal California, fall and spring production occurs in the San Joaquin Valley, CA, and winter production is concentrated in the desert valleys of Yuma County, AZ, and Imperial County, CA $(10,45)$. In all production areas, lettuce drop is one of the most common and destructive diseases, as it is in most other lettuce-growing regions of the world $(22,43,56)$. Crop losses may vary from $<1 \%$ to nearly $75 \%$ (50), and in some cases entire fields may be lost (52).

Lettuce drop is caused by two closely related fungi, Sclerotinia sclerotiorum (Lib.) de Bary and S. minor Jagger. Al-

Corresponding author: Barry M. Pryor

E-mail: bmpryor@u.arizona.edu

Accepted for publication 11 August 2008.

doi:10.1094/PDIS-92-12-1625

(C) 2008 The American Phytopathological Society though both fungi are present in the lettuce growing areas of Arizona and California, their prevalence in the different production regions is somewhat distinct. In the cooler coastal California, $S$. minor is the predominant species, whereas in desert production areas of Yuma and Imperial counties, $S$. sclerotiorum is the predominant species $(21,53)$. Both fungi produce sclerotia, which function as survival propagules and primary inoculum for subsequent lettuce crops. S. minor infects lettuce primarily by hyphae from myceliogenic germination of sclerotia. However, $S$. sclerotiorum may infect either by mycelial germination of sclerotia or by ascospores from apothecia produced by carpogenic germination of sclerotia. The formation of apothecia and subsequent ascospore production depends on soil temperature and moisture $(5,18,53,55)$, and conditions conducive for this are infrequently encountered in desert production areas (39). Thus, the main cause of lettuce drop in the southwestern deserts is through eruptive/direct germination of sclerotia of $S$. sclerotiorum.

Currently, there are no commercial lettuce cultivars with resistance to either Sclerotinia spp. (53). Moreover, crop rotation is not an acceptable management alternative because Sclerotinia spp. have a broad host range and extended survival in soil in the absence of hosts $(14,18,44,53)$. Thus, current management strategies for lettuce drop rely heavily on chemical applications. Fungicides such as dicloran (Botran), iprodione (Rovral), and vinclozolin (Ronilan) have provided a modest level of control of lettuce drop in most situations $(36,39,53)$. However, the ability of iprodione and vinclozolin to control lettuce drop under intensive lettuce production can be short lived due to rapid degradation in soil $(35,53)$. In addition, resistance to iprodione and vinclozolin in Sclerotinia spp. has been reported under laboratory conditions. Moreover, iprodioneresistant strains have exhibited crossresistance against vinclozolin and vice versa $(13,25)$. The heightened concern over pesticide residue on lettuce crops considering the prominence of lettuce in the daily diet, environmental effects from frequent fungicide applications, and a desire for higher level of disease control than that provided by fungicides currently available (39) support the development of nonchemical approaches.

Considerable research has been conducted on evaluating biological control strategies for the management of Sclerotinia species in many cropping systems $(16,23,24,40)$. Most contemporary research involves the use of mycoparasitic fungi that specifically attack fungal hyphae or degrade sclerotia. The most notable of these are Trichoderma spp., Sporidesmium sclerotivorum, and Coniothyrium minitans. Trichoderma spp. are perhaps the most widely used mycoparasites, and numerous commercial formulations exist $(30,34$, 48,57). Trichoderma spp. have been shown to attack both sclerotia and mycelia of Sclerotinia species $(11,12,15,26,27,47$, $54,58)$ and have been used in the field with varying degrees of success (6). In glasshouse tests, Trichoderma reduced lettuce drop by 46 to $72 \%$ compared with untreated control plants (26).

C. minitans and Sporidesmium sclerotivorum are both effective parasites of sclerotia formed by several sclerotiaforming fungi such as Rhizoctonia, Botrytis, and Sclerotinia. Both C. minitans and Sporidesmium sclerotivorum have been used for control of sclerotia-forming fungi in onion, bean, pea, rapeseed, carrot, potato, and chicory $(2,17,41)$. However, to date, only $C$. minitans has been commer- 
cially available $(9,46)$. On lettuce, these agents have been effective in reducing the incidence of lettuce drop by as much as $50 \%$ in glasshouse crops. These results demonstrated the successful application of mycoparasitic fungi for control of lettuce drop and suggested that the development of a successful biocontrol program for desert lettuce production is attainable.

The long-term objective of this study is to develop biocontrol strategies for management of lettuce drop in desert agroecosystems of Arizona and California which may be used independently or in conjunction with standard chemical control strategies. The specific objectives of this study were to: (i) evaluate the efficacy of commercially available biocontrol products in controlling lettuce drop in Arizona and California, and the potential effect of these products on lettuce yield; (ii) evaluate the survival of commercially available biocontrol agents in Arizona and California lettuce fields; and (iii) evaluate the sensitivity of commercially available biocontrol agents to standard fungicides used in lettuce production.

\section{MATERIALS AND METHODS}

Field experiments. Experiments were conducted at the University of Arizona Yuma Agricultural Center, Yuma, AZ, in 2001-2002 and 2002-2003, and at the University of California Desert Agricultural Research and Extension Center, Holtville, CA, in 2002-2003 and 20042005 to evaluate different biocontrol products against lettuce drop caused by $S$. sclerotiorum and $S$. minor. At each location, experiments were designed as a randomized complete block design with four blocks. Each pathogen was studied in separate experiments to evaluate the efficacy of biocontrol and fungicide treatments against lettuce drop caused by each Sclerotinia spp. Results for S. sclerotiorum are reported as experiment $\mathrm{A}$, and results for $S$. minor are reported as experiment B. For all experiments, inoculum consisted of sclerotia of each fungus produced in the lab according to methods described by
Matheron and Porchas (38). For S. sclerotiorum, inoculum was applied to the top of each bed at a rate of $500 \mathrm{ml}$ of sclerotia/grain mixture/15 m bed. For $S$. minor, sclerotia were applied at a rate of $7.5 \mathrm{~g}$ sclerotia/15 $\mathrm{m}$ bed. Time of application of sclerotia on experimental plots was different for the two locations. In the Yuma experiments, inoculum for both fungi was applied by hand on the surface of each planting bed after lettuce thinning at approximately 4 weeks postemergence. In the Holtville experiments, inoculum was applied by hand on the surface of each planting bed immediately before planting and was lightly incorporated into the top centimeter of soil during seeding.

For all trials, the crisphead lettuce cultivar Winterhaven was used as the host. Lettuce was planted on beds with $102 \mathrm{~cm}$ between bed centers with two rows of lettuce spaced $30 \mathrm{~cm}$ apart. At the Yuma location, each treatment plot consisted of a single $15 \mathrm{~m}$ of linear bed, and only every other bed received pathogen inoculum and/or biocontrol or chemical applications to fully separate the effect of each treatment. At the Holtville location, each treatment plot consisted of four adjacent 7.5-m sections of bed. Within each plot, all beds received pathogen inoculum and/or biocontrol or chemical applications, but only the center two beds were evaluated to fully separate the effect of each treatment. Biocontrol agents tested in both Yuma and Holtville experiments included Contans (Coniothyrium minitans; Prophyta, Germany), Plantshield (Trichoderma harzianum; Biowroks, Inc., Victor, NY, USA), and Companion (Bacillus subtilis; Growth Products Ltd., White Plains, NY, USA). In addition, Supresevit (T. harzianum; Binab USA, Inc., Bridgeport, CT, USA) and Soilgard (Gliocladium virens; Certis U.S.A., L.L.C., Columbia, MD, USA) were included in Yuma experiments. Product preparation and application rates were per manufacturer's recommendations (Table 1). Furthermore, at Yuma, each experiment was split into subexperiments with one experiment receiving either a

Table 1. Application rate for biocontrol products and fungicide used in lettuce drop trials in Yuma, AZ, and Holtville, CA

\begin{tabular}{|c|c|c|c|}
\hline Timing of treatment & Treatment $^{y}$ & $\mathbf{A Z}$ application rates ${ }^{\mathbf{Z}}$ & CA application rates ${ }^{\mathrm{z}}$ \\
\hline At planting & $\begin{array}{l}\text { Plantshield } \\
\text { Soilgard } \\
\text { Supresevit } \\
\text { Companion } \\
\text { Contans }\end{array}$ & $\begin{array}{l}8.2 \mathrm{~kg} / \mathrm{ha} \\
37.4 \mathrm{~kg} / \mathrm{ha} \\
4.7 \mathrm{~kg} / \mathrm{ha} \\
4.7 \mathrm{liters} / \mathrm{ha} \\
2.2 \mathrm{~kg} / \mathrm{ha}\end{array}$ & $\begin{array}{l}9.4 \text { liters } / \mathrm{ha} \\
4.4 \mathrm{~kg} / \mathrm{ha}\end{array}$ \\
\hline At thinning & $\begin{array}{l}\text { Plantshield } \\
\text { Soilgard } \\
\text { Supresevit } \\
\text { Companion } \\
\text { Contans } \\
\text { Rovral 4F }\end{array}$ & $\begin{array}{l}16.4 \mathrm{~kg} / \mathrm{ha} \\
74.7 \mathrm{~kg} / \mathrm{ha} \\
9.4 \mathrm{~kg} / \mathrm{ha} \\
9.4 \mathrm{liters} / \mathrm{ha} \\
4.4 \mathrm{~kg} / \mathrm{ha} \\
1.1 \mathrm{~kg} \text { a.i./ha }\end{array}$ & $\begin{array}{l}9.4 \text { liters } / \mathrm{ha} \\
4.4 \mathrm{~kg} / \mathrm{ha} \\
1.1 \mathrm{~kg} \text { a.i./ha }\end{array}$ \\
\hline
\end{tabular}

\footnotetext{
${ }^{\mathrm{y}}$ Soilgard and Supresevit were used only in Yuma trials.

${ }^{\mathrm{z}}$ Plots consisted of $15 \mathrm{~m}$ and $30 \mathrm{~m}$ of bed in Arizona and California, respectively, and only the top of each bed was treated. All treatments were applied in a spray volume of 1.9 liters per $30 \mathrm{~m}$ bed except for Soilgard, which was applied as a dry granule. Rates are per treated hectare.
}

single biocontrol application immediately following planting (experiments A1 for $S$. sclerotiorum and $\mathrm{B} 1$ for $S$. minor) or two applications, one following planting and one following thinning and application of pathogen inoculum (experiments A2 for $S$. sclerotiorum and $\mathrm{B} 2$ for $S$. minor). At Holtville, all biocontrol plots received two applications, one following planting and one following thinning (experiments A2 and B2). A chemical treatment consisting of a single application of Rovral 4F (a.i. = iprodione; Bayer CropScience, Research Triangle Park, NC) applied after thinning (recommended rate $1.11 \mathrm{~kg}$ a.i./ha) was included in each experiment for comparison as a chemical standard frequently used in desert lettuce production.

Furrow and sprinkler irrigation were used in Yuma and Holtville experiments, respectively, for the duration of each trial. All other cultural practices standard for desert lettuce production in Arizona and California were applied for each trial including preplant applications of the herbicide Kerb (a.i. = pronamide; Dow AgroSciences, Indianapolis, IN), preplant and supplemental fertilization, and manual thinning and weeding as needed. At plant maturity and harvest, the numbers of healthy, symptomless lettuce plants per 15 $\mathrm{m}$ of bed were recorded and the percent lettuce drop incidence was calculated. In addition, 10 marketable asymptomatic lettuce heads were collected randomly in each $15-\mathrm{m}$ section of bed and weighed to fully assess the total economic benefits from each treatment (disease reduction and growth stimulation). The effects of different biocontrol agents on yields were calculated by combining data from disease suppression and data from mean head weight at harvest.

Recovery of biocontrol agents from soil. A composite soil sample consisting of 10 randomly collected soil cores $(2.4-\mathrm{cm}$ diameter of the soil core, $7-\mathrm{cm}$ sampling depth) was obtained from each block prior to planting to assess the background population of the biocontrol agents in the experimental areas. Following planting, additional soil sampling was conducted 1 month after the first and second biocontrol treatments were made. A third sampling was done 3 months after the second application to determine the long-term survival of different biocontrol agents in Arizona and California soil under lettuce cultivation. For all soil sampling following planting, a composite consisting of 10 randomly collected soil cores was obtained from each treatment plot. Soil samples were brought to the laboratory, air-dried in paper bags at room temperature for 7 days, and homogenized using a soil processor (Humboldt Mfg. Co., Norridge, IL, USA). For Trichoderma and Gliocladium species, soil dilutions (1/10 and $1 / 100$ in $0.2 \%$ water agar) were plated on Trichoderma selective medium (TSM), and individual 
colonies were enumerated (3). For C. minitans, soil dilutions (1/10 and $1 / 100$ in $0.2 \%$ water agar) were plated on a Coniothyrium selective medium (CSM), and individual colonies were enumerated after 2 weeks of incubation (28). Colony counts for each treatment were averaged and compared among treatments. Recovery and enumeration of Bacillus colonies were not performed.

In vitro fungicide sensitivity test. Sensitivity experiments were conducted with three different fungicides commonly used against lettuce drop: Botran 75 WP (a.i. = dicloran; Gowan Co., Yuma, AZ), Ronilan 50WP (a.i. = vinclozolin; BASF Corp., Research Triangle Park, NC), and Rovral 4F (a.i. = iprodione; Bayer CropScience, Research Triangle Park, NC). Petri dishes containing potato dextrose agar (PDA; Difco) were amended with different fungicides separately at the following rates: 0 , $10,50,100$, and $1,000 \mathrm{ppm}$ a.i. (five replications per fungicide rate). Mycelial plugs were obtained from pure cultures of each biocontrol agent and transferred into the center of dishes containing fungicideamended media and incubated for 10 to 20 days at room temperature $\left(24\right.$ to $\left.26^{\circ} \mathrm{C}\right)$. Colony diameters were measured across two axes of each colony and averaged. Inhibition of fungal growth based upon colony diameter was used to determine the relative level of fungicide activity on each biocontrol agent.

Statistical analysis. Analysis of variance was performed on asymptomatic heads, lettuce head weight, and yield per data to determine the efficacy of different biocontrol agents in suppressing S. sclerotiorum and $S$. minor. A $\chi^{2}$ test for homogeneity of variance for data from each year in each location was carried out to test whether the 2 years of data from Yuma and from Holtville experiments could be combined as single data sets. Analysis of variance was also performed on the fungicide sensitivity data and Trichoderma recovery data from soil. For analyses in which tests for normality failed (e.g., variance equaled zero), the Kruskal-Wallis one-way analysis of variance on ranks was performed. All statistical analyses were conducted using Sigmastat software package (Systat Software Inc., San Jose, CA, USA).

\section{RESULTS}

Effect of different biocontrol products on $S$. sclerotiorum and $S$. minor in field. In Yuma in 2001-2002, the incidence of lettuce drop induced by $S$. sclerotiorum in experiments $\mathrm{A} 1$ and $\mathrm{A} 2$ were 55 and $56 \%$, respectively. In experiment $A 1$, neither a single application of biocontrol treatments nor the application of Rovral resulted in a difference in lettuce drop incidence relative to the inoculated, unsprayed control (Fig. 1). However, in experiment A2, two applications of Contans resulted in a significant increase in the number of asymptomatic heads compared with the infested, unsprayed control ( $x=72$ versus $x=45$, respectively), and it was the only product that demonstrated efficacy. The result from the Rovral treatment was intermediate ( $x=$ 59 healthy heads) and was not significantly different from either the infested, unsprayed control or Contans. Most other treatments using biocontrol agents resulted in fewer healthy heads than the infested, unsprayed control, but were not significantly different $(P>0.05)$. In experiments $\mathrm{B} 1$ and B2 using $S$. minor as inoculum, disease incidence in control plots was 48 and $62 \%$, respectively, and thus disease pressure was similar to that in experiments A1 and A2. However, no biological or chemical treatment resulted in a significant increase in the number of healthy heads at harvest (Fig. 1).

Results were similar for experiments conducted in 2002-2003. Disease incidence in experiments $\mathrm{A} 1$ and $\mathrm{A} 2$ was 63 and $59 \%$, respectively (Fig. 2). In experiment $\mathrm{A} 1$, no treatments resulted in statistically significant increases in the number of

\section{1-02}
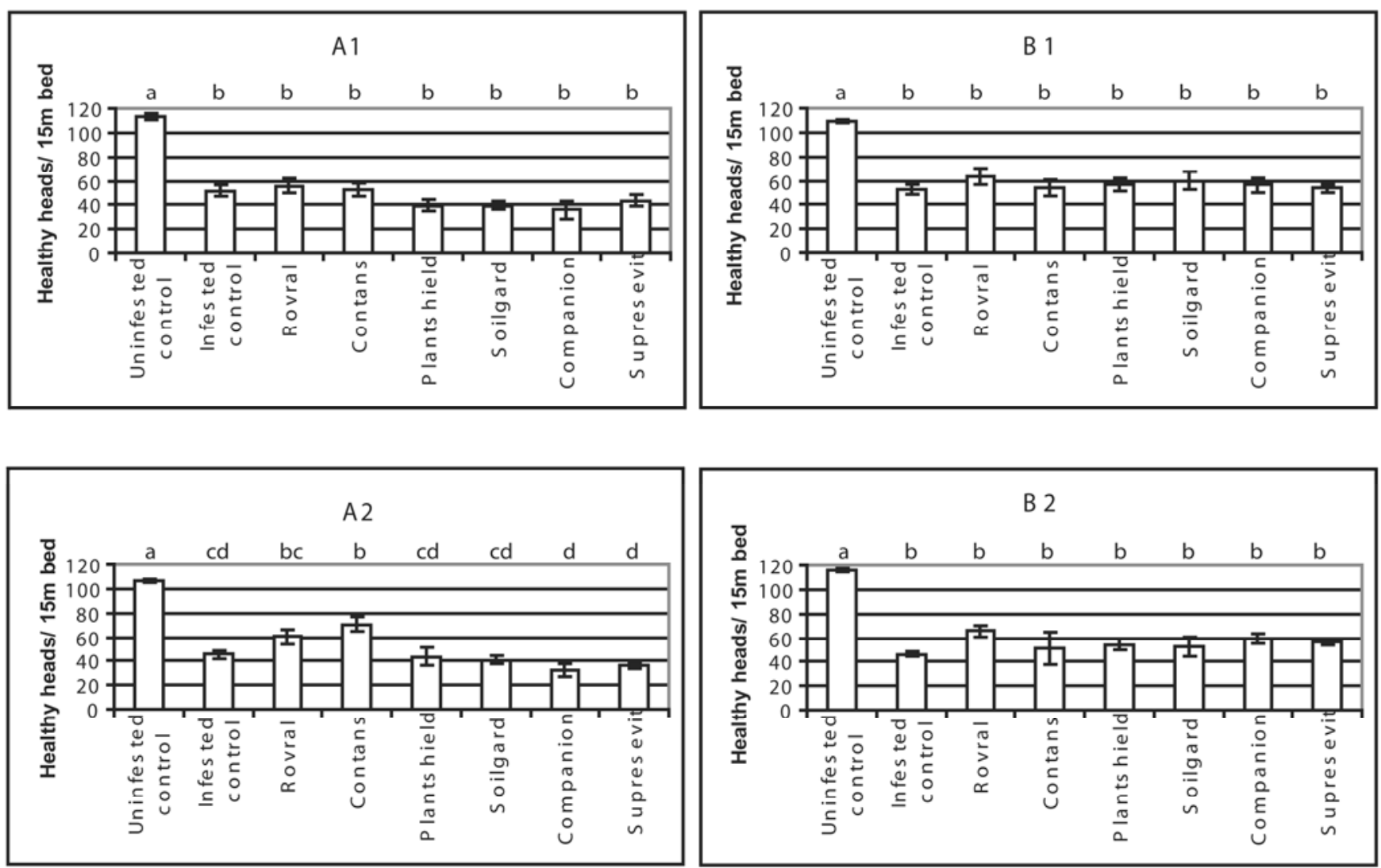

Fig. 1. Effect of different biocontrol products and Rovral sprays on number of healthy lettuce heads at harvest in plots artificially infested with either Sclerotinia sclerotiorum or S. minor in 2001-2002 experiment in Yuma, AZ. Columns with different letters are significantly different according to Tukey's test $(P<0.05)$. 
healthy lettuce heads relative to the infested, unsprayed control (Fig. 2). However, in experiment A2, two applications of Contans again resulted in a significant increase in the number of asymptomatic heads over the control ( $x=60$ versus $x=$ 42 , respectively), and it was the only product that demonstrated efficacy. The results from the Rovral treatment were intermediate ( $x=54$ asymptomatic heads) and were not significantly different from either the control or Contans. In experiments B1 and B2 using $S$. minor as inoculum, disease incidence in control plots was 30 and $29 \%$, respectively. However, similar to 20012002 trials, neither one nor two applications of any product resulted in statistically significant increases in the number of asymptomatic lettuce heads compared with the control, albeit at the lower disease pressure (Fig. 2).

Results from experiments in Holtville, $\mathrm{CA}$, were similar to the results from Yuma experiments. As there were no significant differences between the 2 years of data, data were pooled and analyzed as one data set. In experiment A2 on S. sclerotiorum, the incidence of disease was approximately $51 \%$, similar to that observed in Yuma experiments. Two applications of
Contans resulted in a significant increase in the number of asymptomatic heads over the control ( $x=114$ versus $x=57.5)$, and the number of asymptomatic heads produced in Contans-treated plots was almost equal to that of the uninfested, unsprayed control ( $x=114$ versus $x=117$ ) (Fig. 3). The other biocontrol agents and Rovral did not result in a greater number of asymptomatic heads over the infested, unsprayed control. As in Yuma studies, no treatment at Holtville was effective against $S$. minor in either year (Fig. 3).

In Yuma in 2001-2002, no significant increase in head weight was observed with any product either in one or two applications in all four experiments (Table 2). In experiments $\mathrm{A}$ and $\mathrm{B}$, both one and two applications of Contans, Soilgard, and Companion resulted in numerically higher head weight compared with uninfested, untreated control, but the differences were not statistically significant. In contrast, Rovral resulted in numerically lower head weight than the control, and the lowest head weight in all experiments, but again statistically not significant from other treatments. In 2002-2003 again neither one nor two applications of any treatment increased head weight significantly (Table
2). Similarly, in the Holtville experiments, head weight was not increased by any product in either experiment (Table 3). Head weight in both trials with Rovral was the lowest of all treatments.

Even though Contans resulted in the highest numerical yield of all treatments in experiment A1, the yield was not significantly different from other treatments during both 2001-2002 and 2002-2003 in Yuma experiments (Table 4). In experiment A2, two applications of Contans resulted in a statistically significant yield increase relative to the uninfested, unsprayed control during both years. None of the other treatments increased yield significantly over the inoculated, unsprayed control. In experiment B1, there were no statistically significant differences in yield among the various treatments in 2001-2002. In 2002-2003, no treatment significantly increased the yield over control.

In experiment A2 at Holtville, Contans resulted in a significant increase in yield over the control, and this yield was nearly equal to that from the uninfested, unsprayed control (Table 3). Yield increases with Rovral and other biocontrol agents were not significantly different from in-

\section{2-03}
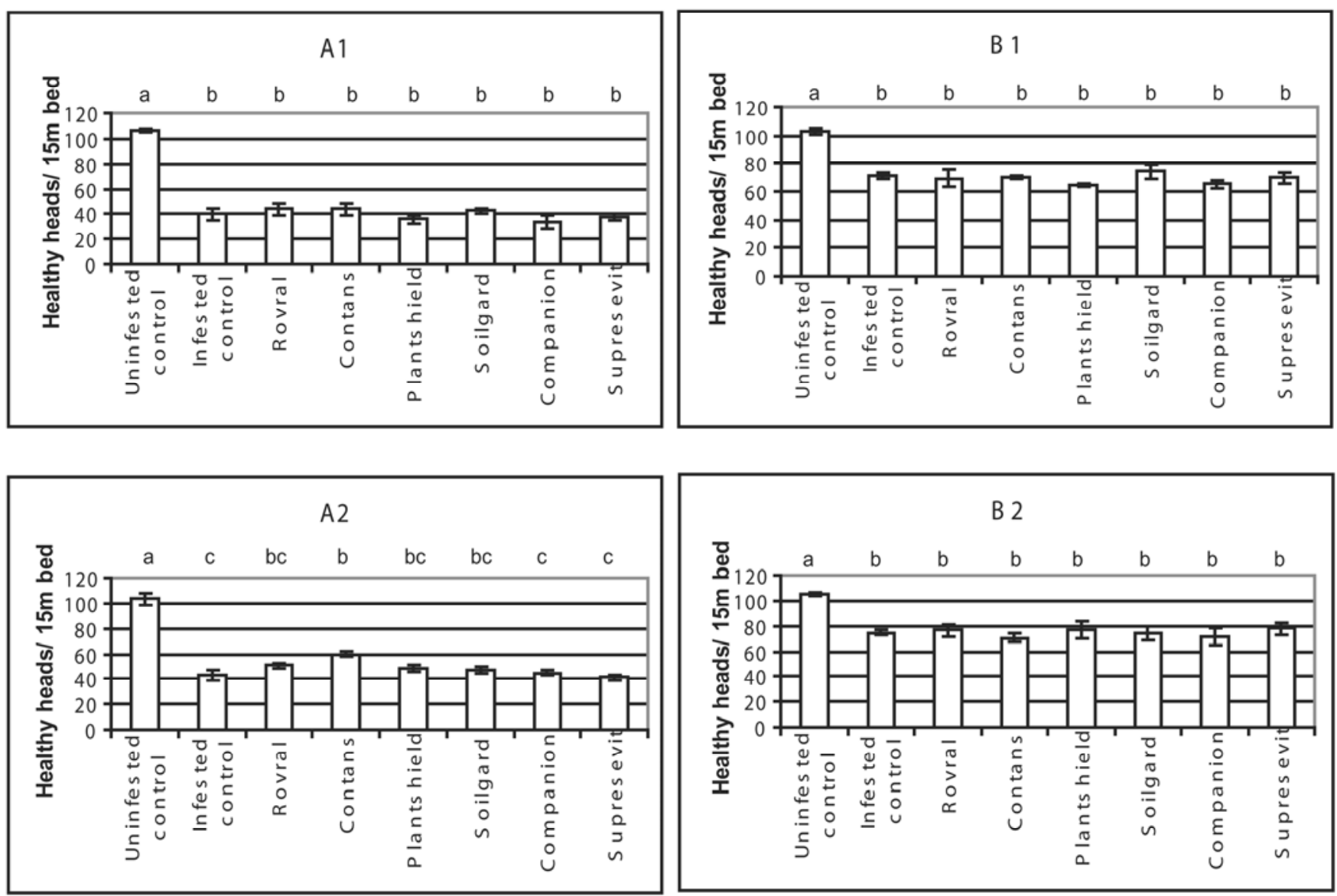

Fig. 2. Effect of different biocontrol products and Rovral sprays on number of healthy lettuce heads at harvest in plots artificially infested with either Sclerotinia sclerotiorum or S. minor in 2002-2003 experiment in Yuma, AZ. Columns with different letters are significantly different according to Tukey's test $(P<0.05)$. 
oculated, unsprayed control. In experiment B2, there were no statistically significant differences in yield among the various treatments (Table 3). However, Contans resulted in numerically higher yield followed by Rovral (Table 3 ).
Survival of different biocontrol agents in treatment plots. Results from 20012002 experiments A and B conducted at Yuma were very similar (Table 5). Background Trichoderma or Gliocladium was not detected in Yuma soils (data not

\section{Two applications}
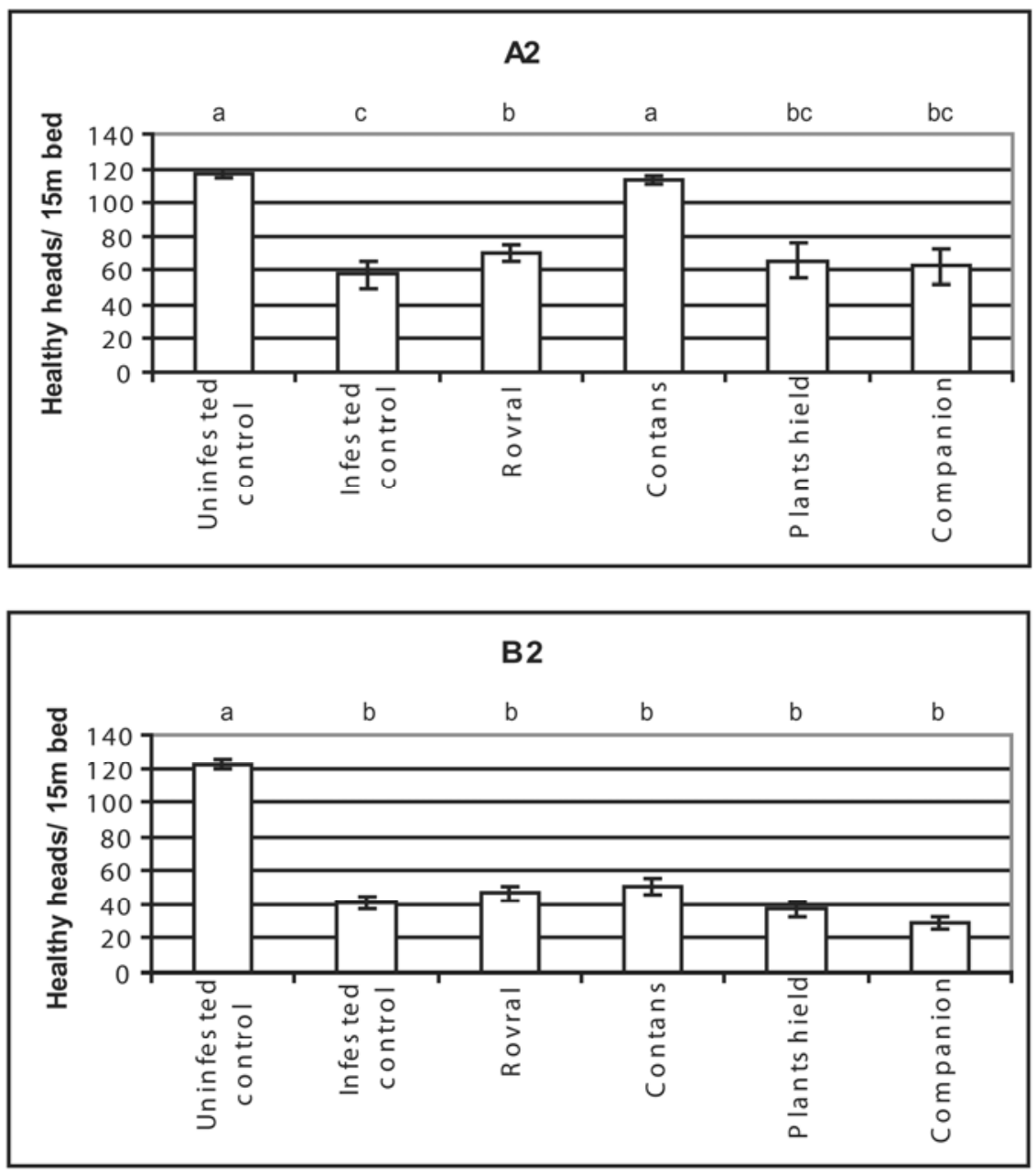

Fig. 3. Effect of different biocontrol products and Rovral sprays on number of healthy lettuce heads at harvest in plots artificially infested with either Sclerotinia sclerotiorum or S. minor in Holtville, CA. Columns with different letters are significantly different according to Tukey's test $(P<0.05)$. shown). On 15 December, 1 month after the initial treatment, low to moderate levels of Trichoderma/Gliocladium were detected in all corresponding treated soils. On 15 January, 1 month after the second application, Trichoderma/Gliocladium was still detected in the corresponding plots, although significant colony forming units (CFU) were recorded only for plots treated with Supresevit. In trials A2 and B2, which received a second application of biocontrol product, Trichoderma populations in the Supresevit plots were 3 to 5 times higher than in treatments that received only one application. By the final soil sampling on 15 March, 3 months after the last treatment, Trichoderma was detected in high numbers only in plots treated with Supresevit. In plots that received two applications of Supresevit, Trichoderma population levels were 2 to 3.5 times higher than those in plots having received only one application. Results were similar in 20022003 (Table 6).

Similarly, at Holtville, no background Trichoderma was detected in the soil at the beginning of the experiment (data not shown) and only trace amounts were detected in treatments that did not receive a Trichoderma-containing product. On 5 December, 1 month after the initial treatment, low levels of Trichoderma were detected in plots to which a Trichodermacontaining product was added in both experiments $\mathrm{A}$ and $\mathrm{B}$, but the number of $\mathrm{CFU}$ in experiment $\mathrm{A}$ was higher than that in experiment B (Table 7). On 6 January, 1 month after the second application, significant numbers of Trichoderma CFU were detected in plots treated with Plantshield in both trials. Trichoderma populations in Plantshield-applied plots on 6 February were 3 times higher in experiment $\mathrm{A}$ and 16 times higher in experiment $B$ than those in plots that received the product on only 5 December. By 7 March, 3 months after the last treatment and the final soil sampling period, a significantly high number of Trichoderma CFU was still detected in

Table 2. Effect of application of different biocontrol products and Rovral on lettuce head weight in plots infested either with Sclerotinia sclerotiorum or S. minor in Yuma, AZ, trials

\begin{tabular}{|c|c|c|c|c|c|c|c|c|}
\hline \multirow[b]{4}{*}{ Treatments } & \multicolumn{8}{|c|}{ Head weight $(\mathrm{kg})^{\mathrm{w}}$} \\
\hline & \multicolumn{4}{|c|}{ 2001-2002 } & \multicolumn{4}{|c|}{$2002-2003$} \\
\hline & \multicolumn{2}{|c|}{ S. sclerotiorum } & \multicolumn{2}{|c|}{ S. minor } & \multicolumn{2}{|c|}{ S. sclerotiorum } & \multicolumn{2}{|c|}{ S. minor } \\
\hline & $\mathbf{A} 1^{\mathbf{x}}$ & $\mathbf{A 2}^{\mathbf{y}}$ & B1 ${ }^{\mathbf{x}}$ & B2y & $\mathbf{A 1}^{\mathrm{x}}$ & $\mathbf{A 2}^{\mathbf{y}}$ & $\mathbf{B 1}^{\mathbf{x}}$ & B2y \\
\hline Uninfested control & $24.98 \mathrm{a}$ & $25.23 \mathrm{a}$ & $20.25 \mathrm{a}$ & $18.25 \mathrm{a}$ & $23.20 \mathrm{a}$ & $24.10 \mathrm{a}$ & $22.70 \mathrm{a}$ & $24.20 \mathrm{a}$ \\
\hline Infested control & $25.95 \mathrm{a}$ & $24.20 \mathrm{a}$ & $19.35 \mathrm{a}$ & $19.30 \mathrm{a}$ & $21.90 \mathrm{a}$ & $22.90 \mathrm{a}$ & $22.13 \mathrm{a}$ & $23.80 \mathrm{a}$ \\
\hline Rovral $^{z}$ & $23.95 \mathrm{a}$ & $24.05 \mathrm{a}$ & $17.03 \mathrm{a}$ & $17.28 \mathrm{a}$ & $21.50 \mathrm{a}$ & $22.40 \mathrm{a}$ & $21.98 \mathrm{a}$ & $23.60 \mathrm{a}$ \\
\hline Contans & $26.43 \mathrm{a}$ & $25.45 \mathrm{a}$ & $21.35 \mathrm{a}$ & $21.18 \mathrm{a}$ & $23.00 \mathrm{a}$ & $22.70 \mathrm{a}$ & $23.38 \mathrm{a}$ & $24.00 \mathrm{a}$ \\
\hline Plantshield & $25.68 \mathrm{a}$ & $24.65 \mathrm{a}$ & $18.40 \mathrm{a}$ & $20.15 \mathrm{a}$ & $22.23 \mathrm{a}$ & $23.30 \mathrm{a}$ & $23.60 \mathrm{a}$ & $24.40 \mathrm{a}$ \\
\hline Soilgard & $27.50 \mathrm{a}$ & $26.30 \mathrm{a}$ & $21.03 \mathrm{a}$ & $21.55 \mathrm{a}$ & $22.80 \mathrm{a}$ & $22.90 \mathrm{a}$ & $23.93 \mathrm{a}$ & $23.30 \mathrm{a}$ \\
\hline Companion & $26.20 \mathrm{a}$ & $24.93 \mathrm{a}$ & $20.40 \mathrm{a}$ & $21.73 \mathrm{a}$ & $22.58 \mathrm{a}$ & $23.70 \mathrm{a}$ & $23.70 \mathrm{a}$ & $24.30 \mathrm{a}$ \\
\hline Supresevit & $25.33 \mathrm{a}$ & $24.38 \mathrm{a}$ & $18.53 \mathrm{a}$ & $18.90 \mathrm{a}$ & $23.45 \mathrm{a}$ & $22.20 \mathrm{a}$ & $23.53 \mathrm{a}$ & $23.70 \mathrm{a}$ \\
\hline
\end{tabular}

${ }^{\text {w }}$ Total weight of 10 marketable heads collected randomly from each treatment plot at harvest. Columns with different letters are significantly different according to the Holm-Sidak test $(P<0.05)$.

${ }^{\mathrm{x}}$ Treatments consisted of single spray of different biocontrol products at the time of planting.

y Treatment consisted of two sprays, one at planting and one immediately after thinning.

${ }^{\mathrm{z}}$ Fungicide Rovral applied only once immediately after thinning in all experiments. 
plots treated with Plantshield in both trials. The number of CFU of Trichoderma in experiment B was nearly two times higher than that in experiment A (Table 7).

$C$. minitans populations were not determined in 2001-2002 experiments. Soil densities of $C$. minitans were determined in the 2002-2003 experiment at both Yuma and Holtville. At the onset of each trial, no back- ground C. minitans was detected at either location. In subsequent sampling, only three soil samples collected at harvest from experiment B2 in Yuma, which received two applications, and two samples collected from experiment A2 in Holtville were positive for the presence of $C$. minitans at average soil population densities of $12.5 \mathrm{CFU} / \mathrm{g}$ and 2.5 $\mathrm{CFU} / \mathrm{g}$ of soil, respectively.

Table 3. Effect of application of different biocontrol products and Rovral on lettuce head weight and yield in plots infested either with Sclerotinia sclerotiorum (trial A2) or S. minor (trial B2) in 2-year experiments in Holtville, CA

\begin{tabular}{|c|c|c|c|c|}
\hline \multirow[b]{2}{*}{ Treatments $^{y}$} & \multicolumn{2}{|c|}{ Head weight $(\mathrm{kg})^{\mathrm{w}}$} & \multicolumn{2}{|c|}{ Yield $(\mathrm{kg})^{\mathrm{x}}$} \\
\hline & Trial A2 & Trial B2 & Trial A2 & Trial B2 \\
\hline Uninfested control & $17.53 \mathrm{a}$ & $20.29 a$ & $206.87 \mathrm{a}$ & $220.55 \mathrm{a}$ \\
\hline Infested control & $17.49 \mathrm{a}$ & $24.89 \mathrm{a}$ & $88.79 \mathrm{~b}$ & $73.70 \mathrm{~b}$ \\
\hline Rovral $^{z}$ & $16.69 \mathrm{a}$ & $21.61 \mathrm{a}$ & $111.90 \mathrm{~b}$ & $80.03 \mathrm{~b}$ \\
\hline Contans & $16.81 \mathrm{a}$ & $22.23 \mathrm{a}$ & $192.51 \mathrm{a}$ & $93.47 \mathrm{~b}$ \\
\hline Plantshield & $16.71 \mathrm{a}$ & $23.9 \mathrm{a}$ & $96.34 \mathrm{~b}$ & $64.92 \mathrm{~b}$ \\
\hline Companion & $17.41 \mathrm{a}$ & $24.56 \mathrm{a}$ & $93.27 \mathrm{~b}$ & $54.25 \mathrm{~b}$ \\
\hline
\end{tabular}

${ }^{\text {w }}$ Sums of weight of 10 marketable heads collected randomly from the three replicated treatment plots at harvest.

${ }^{\mathrm{x}}$ Yields were calculated by combining data from disease suppression and data from mean head weight at harvest. Columns with different letters are significantly different according to the Holm-Sidak test $(P<0.05)$.

y Treatments consisted of two sprays, one at planting and one immediately after thinning.

${ }^{\mathrm{z}}$ Fungicide Rovral applied only once immediately after thinning in all experiments.
In vitro evaluation of fungicide sensitivity. Trichoderma isolates in Plantshield and Supresevit were very tolerant to the three fungicides, Rovral, Botran, and Ronilan, at 1,000 ppm a.i. (Fig. 4). Gliocladium from Soilgard was very tolerant to Rovral and Botran at 1,000 ppm a.i. and tolerant to Ronilan up to $100 \mathrm{ppm}$ a.i. (Fig. 4). C. minitans was very sensitive to all three fungicides above $1 \mathrm{ppm}$ a.i. Both $S$. sclerotiorum and $S$. minor were also quite sensitive to the two fungicides Ronilan and Rovral in concentrations over $1 \mathrm{ppm}$ a.i., and S. sclerotiorum was sensitive to Botran in concentrations over $10 \mathrm{ppm}$ a.i. Similar results were obtained in repeated experiments (data not shown).

\section{DISCUSSION}

This study demonstrated that C. minitans outperformed all other products tested, including the fungicide iprodione, in suppressing lettuce drop caused by $S$. sclerotiorum. At both locations, C. minitans effectively suppressed $S$. sclerotiorum and increased lettuce head weight, and consequently yield, when it was applied twice during the crop cycle: once at planting and once at thinning. Although the

Table 4. Effect of application of different biocontrol products and Rovral on lettuce yield in plots infested either with Sclerotinia sclerotiorum or S. minor in Yuma, AZ, trials

\begin{tabular}{|c|c|c|c|c|c|c|c|c|}
\hline \multirow[b]{4}{*}{ Treatments } & \multicolumn{8}{|c|}{ Yield $(\mathbf{k g})^{\mathrm{w}}$} \\
\hline & \multicolumn{4}{|c|}{ 2001-2002 } & \multicolumn{4}{|c|}{$2002-2003$} \\
\hline & \multicolumn{2}{|c|}{ S. sclerotiorum } & \multicolumn{2}{|c|}{ S. minor } & \multicolumn{2}{|c|}{ S. sclerotiorum } & \multicolumn{2}{|c|}{ S. minor } \\
\hline & $\mathbf{A} 1^{x}$ & $\mathbf{A 2}^{\mathrm{y}}$ & B1 $^{x}$ & $\mathbf{B 2}^{\mathrm{y}}$ & $\mathbf{A} 1^{x}$ & $\mathbf{A} 2^{y}$ & B1 $^{x}$ & $B 2^{y}$ \\
\hline Uninfested control & $282.9 \mathrm{a}$ & $268.9 \mathrm{a}$ & $221.1 \mathrm{a}$ & $210.9 \mathrm{a}$ & $247.3 \mathrm{a}$ & $249.0 \mathrm{a}$ & $233.7 \mathrm{a}$ & $254.1 \mathrm{a}$ \\
\hline Infested control & $133.6 \mathrm{~b}$ & $108.9 \mathrm{~cd}$ & $101.5 \mathrm{~b}$ & $80.4 \mathrm{~b}$ & $86.7 \mathrm{~b}$ & $96.7 \mathrm{c}$ & $158.1 \mathrm{~b}$ & $177.4 \mathrm{~b}$ \\
\hline Rovral $^{2}$ & $129.6 \mathrm{~b}$ & $144.9 \mathrm{bc}$ & $106.5 \mathrm{~b}$ & $125.9 \mathrm{~b}$ & $93.4 \mathrm{~b}$ & $114.7 \mathrm{bc}$ & $153.1 \mathrm{~b}$ & $179.6 \mathrm{~b}$ \\
\hline Contans & $138.4 \mathrm{~b}$ & $171.4 \mathrm{~b}$ & $115.5 \mathrm{~b}$ & $90.9 \mathrm{~b}$ & $101.5 \mathrm{~b}$ & $135.2 \mathrm{~b}$ & $163.4 \mathrm{~b}$ & $186.6 \mathrm{~b}$ \\
\hline Plantshield & $102.6 \mathrm{~b}$ & $109.4 \mathrm{~cd}$ & $104.7 \mathrm{~b}$ & $108.6 \mathrm{~b}$ & $80.1 \mathrm{~b}$ & $112.5 \mathrm{bc}$ & $151.5 \mathrm{~b}$ & $171.3 \mathrm{~b}$ \\
\hline Soilgard & $109.6 \mathrm{~b}$ & $106.2 \mathrm{~cd}$ & $124.8 \mathrm{~b}$ & $116.0 \mathrm{~b}$ & $96.1 \mathrm{~b}$ & $108.8 \mathrm{bc}$ & $176.1 \mathrm{~b}$ & $171.1 \mathrm{~b}$ \\
\hline Companion & $96.0 \mathrm{~b}$ & $81.4 \mathrm{~d}$ & $112.9 \mathrm{~b}$ & $128.2 \mathrm{~b}$ & $74.9 \mathrm{~b}$ & $106.5 \mathrm{bc}$ & $155.1 \mathrm{~b}$ & $172.8 \mathrm{~b}$ \\
\hline Supresevit & $110.4 \mathrm{~b}$ & $86.5 \mathrm{~cd}$ & $99.6 \mathrm{~b}$ & $118.6 \mathrm{~b}$ & 88.8 & $92.3 \mathrm{c}$ & $165.4 \mathrm{~b}$ & $182 \mathrm{~b}$ \\
\hline
\end{tabular}

${ }^{w}$ Yields were calculated by combining data from disease suppression and data from mean head weight at harvest. Columns with different letters are significantly different according to the Holm-Sidak test $(P<0.05)$.

${ }^{x}$ Treatments consisted of single sprays of different biocontrol products at time of planting.

${ }^{y}$ Treatment consisted of two sprays, one at planting and one immediately after thinning.

${ }^{\mathrm{z}}$ Fungicide Rovral applied only once immediately after thinning in all experiments.

Table 5. Recovery of Trichoderma and Gliocladium spp. in treatment plots before and after biocontrol agent application in Sclerotinia spp. experiments in Yuma, AZ, 2001-2002

\begin{tabular}{|c|c|c|c|c|c|c|c|c|c|c|c|c|}
\hline \multirow[b]{4}{*}{ Treatments } & \multicolumn{12}{|c|}{ Recovery of biocontrol agents (CFU/g of soil) } \\
\hline & \multicolumn{6}{|c|}{ S. sclerotiorum } & \multicolumn{6}{|c|}{ S. minor } \\
\hline & \multicolumn{3}{|c|}{$\mathbf{A 1}^{\mathbf{y}}$} & \multicolumn{3}{|c|}{ A2 } & \multicolumn{3}{|c|}{ B1 } & \multicolumn{3}{|c|}{ B2 } \\
\hline & $\mathbf{1}^{\mathrm{z}}$ & 2 & 3 & 1 & 2 & 3 & 1 & 2 & 3 & $\mathbf{1}$ & 2 & 3 \\
\hline Plantshield & $44 \mathrm{a}$ & $9 \mathrm{a}$ & $18 \mathrm{a}$ & $44 \mathrm{a}$ & $47 \mathrm{~b}$ & $9 \mathrm{a}$ & $91 \mathrm{a}$ & $13 \mathrm{a}$ & $19 \mathrm{a}$ & $91 \mathrm{a}$ & $94 \mathrm{a}$ & $28 \mathrm{a}$ \\
\hline Supersivit & $169 \mathrm{a}$ & $156 \mathrm{a}$ & $121 \mathrm{~b}$ & $169 \mathrm{a}$ & $472 \mathrm{c}$ & $250 \mathrm{~b}$ & $41 \mathrm{a}$ & $71 \mathrm{~b}$ & $175 \mathrm{a}$ & $41 \mathrm{a}$ & $347 \mathrm{~b}$ & $600 \mathrm{~b}$ \\
\hline Soilgard & $9 \mathrm{a}$ & $22 \mathrm{a}$ & $5 \mathrm{a}$ & $9 \mathrm{a}$ & $6 \mathrm{a}$ & $41 \mathrm{ab}$ & $9 \mathrm{a}$ & $12 \mathrm{a}$ & 0 & $9 \mathrm{a}$ & $16 \mathrm{a}$ & $9 \mathrm{a}$ \\
\hline Companion & 0 & 6 & 1 & 0 & 0 & 9 & 0 & 3 & 0 & 0 & 0 & 0 \\
\hline Contans & 0 & 0 & 0 & 0 & 0 & 0 & 0 & 0 & 0 & 0 & 0 & 0 \\
\hline Rovral & 0 & 0 & 0 & 0 & 0 & 3 & 0 & 0 & 0 & 0 & 0 & 0 \\
\hline Infested control & 0 & 0 & 0 & 0 & 0 & 0 & 0 & 0 & 0 & 0 & 0 & 0 \\
\hline
\end{tabular}

y A1 and B1, plots received only one application; A2 and B2, plots received two applications, one at planting and one after thinning. Columns with different letters are significantly different according to Tukey's test $(P<0.05)$.

${ }^{\mathrm{z}}$ Soil sampling was done: 1, 1 month after first treatment; 2, 1 month after second treatment; 3, 3 months after second treatment. No Trichoderma/Gliocladium spp. were recovered from plot soil prior to start of trial. 
results from the two locations with regard to the performance of $C$. minitans against $S$. sclerotiorum were consistent, the locations differed with respect to the level of disease incidence and the level of disease suppression. In the Yuma experiments, the level of control achieved with Contans was modest. In contrast, control of lettuce drop caused by $S$. sclerotiorum was nearcomplete despite higher disease incidence in the Holtville experiments. The reasons for differences between the Yuma and Holtville experiments may be related to two notable differences in the experimental methods. At Holtville, pathogen inoculum was applied at the beginning of the season as opposed to at thinning in the Yuma experiment. While this facilitated a greater interaction between the susceptible lettuce plants and $S$. sclerotiorum, leading to higher lettuce drop incidence, it also facilitated a greater interaction between the biocontol agent, $C$. minitans, and the pathogen, S. sclerotiorum, contributing to effective parasitism of sclerotia and the corresponding disease suppression. Another experimental difference between the two locations is the method of irrigation. At Holtville, the lettuce crops were irrigated using overhead sprinklers in contrast to the furrow irrigation employed at Yuma. Previous studies have revealed that $C$. minitans is effectively splash-dispersed by sprinklers in greenhouse studies (5). It is quite likely that the sprinkler irrigation employed in the Holtville experiment increased the dispersal of $C$. minitans following initial applications, resulting in near complete parasitism of $S$. sclerotiorum sclerotia. This is consistent with previous studies on the control of S. sclerotiorum using $C$. minitans in lettuce $(7,9,11,29,38)$ and on the biocontrol of Sclerotinia diseases of bean $(6,19,32,33)$. Additionally, the survival of $C$. minitans may have been enhanced under sprinkle irrigation due to the maintenance of more even soil moisture over the course of the growing season compared to greater fluctuation in periods of wetting and drying that occur under furrow irrigation. However, further studies would be needed to support these hypotheses.

In contrast to the successful suppression of infection by $S$. sclerotiorum, C. minitans did not suppress lettuce drop caused by $S$. minor. Nearly all previous studies $(1,46)$ also reported lack of efficacy of $C$. minitans against $S$. minor. However, Ridgway et al. (51) reported that $C$. minitans successfully controlled lettuce drop caused by S. minor and increased lettuce yield significantly. On Sclerotinia blight of peanut, C. minitans did not provide significant disease suppression during the first year of soil application, but subsequent application over consecutive years significantly reduced disease incidence (46). Although $S$. sclerotiorum and $S$. minor are closely related fungi, the differential efficacy in field experiments presented in this work was puzzling and requires further scrutiny.

Previous studies on the differential efficacy of $C$. minitans against the two Sclerotinia species have attributed it to differences in the quality and quantity of diffusible sclerotial exudates between the two species. Grendene and Marciano (20) found that $C$. minitans grew more rapidly toward autoclaved sclerotia of S. sclerotiorum than toward live sclerotia because of increased amounts of nutrients released to the media. Since sclerotia of $S$. minor are smaller than those of $S$. sclerotiorum, the amount of exudates diffused by $S$. minor sclerotia may not be sufficient to stimulate $C$. minitans growth toward the sclerotial target. Although earlier studies showed that sclerotial exudates from both Sclerotinia species stimulated C. minitans mycelial growth $(20,51)$, there is no information about the specific components of the exudates that act as the primary stimuli or if these components are differentially present. This information may be helpful toward enhancement of parasitism of $C$. minitans against $S$. minor.

Trichoderma-based biocontrol products were not effective in suppressing $S$. sclerotiorum at both locations. This is consistent with the findings of Gerlagh et al. (18) on S. sclerotiorum in beans. Interestingly, the number of healthy heads in plots treated with Trichoderma, Gliocladium, and Bacillus-based biocontrol products were in general lower than those in the control. The possibility that these products stimulated infection of lettuce by $S$. sclerotiorum cannot be discounted. Budge and Whipps (8) showed that Trichoderma spp. stimulated the production of sclerotia by $S$. sclerotiorum and the number of apothecia produced by sclerotia compared with nontreated controls on celery and lettuce.

Post-application recovery of $C$. minitans from soil was low in both locations. The reasons for poor recovery despite high infestation levels are unclear but perhaps

Table 7. Recovery of Trichoderma sp. in treatment plots before and after biocontrol agent application experiments in Holtville, CA, in 2002-2003

\begin{tabular}{lccccccc}
\hline & \multicolumn{5}{c}{ Recovery of biocontrol agents (CFU/g of soil) } \\
\cline { 2 - 4 } \cline { 2 - 4 } \cline { 6 - 8 } Treatments & $\mathbf{1}^{\mathbf{z}}$ & $\mathbf{2}$ & $\mathbf{3}$ & & $\mathbf{1}$ & $\mathbf{2}$ & $\mathbf{3}$ \\
\hline Plantshield & $100 \mathrm{a}$ & $312 \mathrm{ab}$ & $477 \mathrm{a}$ & & $25 \mathrm{a}$ & $401 \mathrm{ab}$ & $842 \mathrm{~b}$ \\
Companion & 0 & 0 & 14 & & 0 & 0 & 0 \\
Contans & 0 & 0 & 0 & & 0 & 0 & 0 \\
Rovral & 0 & 0 & 0 & & 0 & 0 & 0 \\
Infested control & 0 & 0 & 0 & & 0 & 0 & 0 \\
\hline
\end{tabular}

${ }^{\mathrm{z}}$ Soil sampling was done: 1, 1 month after first treatment; 2, 1 month after second treatment; 3, 3 months after second treatment. No Trichoderma spp. were recovered from plot soil prior to start of trial. Columns with different letters are significantly different according to Tukey's test $(P<0.05)$.

Table 6. Recovery of Trichoderma and Gliocladium spp. in treatment plots before and after biocontrol agent application in Sclerotinia spp. experiments in Yuma, AZ, in 2002-2003

\begin{tabular}{|c|c|c|c|c|c|c|c|c|c|c|c|c|}
\hline \multirow[b]{4}{*}{ Treatments } & \multicolumn{12}{|c|}{ Recovery of biocontrol agents (CFU/g of soil) } \\
\hline & \multicolumn{6}{|c|}{ S. sclerotiorum } & \multicolumn{6}{|c|}{ S. minor } \\
\hline & \multicolumn{3}{|c|}{$\mathbf{A 1}^{\mathbf{y}}$} & \multicolumn{3}{|c|}{ A2 } & \multicolumn{3}{|c|}{ B1 } & \multicolumn{3}{|c|}{ B2 } \\
\hline & $\mathbf{1}^{\mathbf{z}}$ & 2 & 3 & 1 & 2 & 3 & 1 & 2 & 3 & 1 & 2 & 3 \\
\hline Plantshield & $85 \mathrm{ab}$ & $98 \mathrm{ab}$ & $204 \mathrm{a}$ & $85 a b$ & $198 \mathrm{ab}$ & $218 \mathrm{a}$ & $39 \mathrm{a}$ & $26 \mathrm{a}$ & $254 \mathrm{a}$ & $39 \mathrm{a}$ & $176 \mathrm{a}$ & $284 \mathrm{~b}$ \\
\hline Supresevit & $468 \mathrm{~b}$ & $134 \mathrm{~b}$ & $88 \mathrm{a}$ & $468 \mathrm{~b}$ & $251 \mathrm{~b}$ & $280 \mathrm{a}$ & $222 \mathrm{~b}$ & $80 \mathrm{~b}$ & $255 \mathrm{a}$ & $222 \mathrm{~b}$ & $209 a$ & $314 \mathrm{~b}$ \\
\hline Soilgard & $1 \mathrm{a}$ & $4 \mathrm{a}$ & $1 \mathrm{a}$ & $1 \mathrm{a}$ & $9 \mathrm{a}$ & $5 \mathrm{~b}$ & $3 \mathrm{a}$ & $5 \mathrm{a}$ & $5 \mathrm{~b}$ & $3 \mathrm{a}$ & $8 \mathrm{a}$ & $0 \mathrm{a}$ \\
\hline Companion & 0 & 0 & 0 & 0 & 1 & 0 & 4 & 3 & 0 & 4 & 3 & 0 \\
\hline Contans & 0 & 0 & 0 & 0 & 0 & 0 & 0 & 0 & 0 & 0 & 0 & 0 \\
\hline Rovral & 0 & 0 & 0 & 0 & 0 & 0 & 0 & 0 & 0 & 0 & 0 & 0 \\
\hline Infested control & 0 & 0 & 0 & 0 & 3 & 0 & 1 & 0 & 0 & 1 & 0 & 3 \\
\hline
\end{tabular}

${ }^{y} \mathrm{~A} 1$ and B1, plots received only one application; A2 and B2, plots received two applications, one at planting and one after thinning. Columns with different letters are significantly different according to Tukey's test $(P<0.05)$.

${ }^{\mathrm{z}}$ Soil sampling was done: 1, 1 month after first treatment; 2, 1 month after second treatment; 3, 3 months after second treatment. No Trichoderma/Gliocladium spp. were recovered from plot soil prior to the start of the trial. 
include a nonoptimal method of recovery for such a specialized fungus. It has been shown that $C$. minitans is a poor competitor for resources in the general soil environment and is particularly well adapted to colonize sclerotia of $S$. sclerotiorum for survival. It survives well as conidia within sclerotia of S. sclerotiorum and as conidial droplets on the surface of the sclerotial rind (4). Thus, the specific collection of sclerotia from the field and subsequent culturing directly from sclerotia would be a more appropriate method for recovery of
C. minitans than simply the collection of soil from the field and plating on semiselective media. Nonetheless, despite the low recovery, it was the best product for suppressing $S$. sclerotiorum. This suggests that low populations of highly effective organisms are perhaps sufficient for significant disease suppression in some pathosystems (19).

The effects of Trichoderma products on $S$. minor were similar at both locations although most applications of Trichoderma, Gliocladium, and Bacillus-based products in the Yuma experiments generally resulted in numerically greater or equal numbers of healthy heads in trials with $S$. minor than at Holtville. Members of the genus Trichoderma are distributed worldwide and are frequently recovered from soil and samples of vegetation (49). Our study showed that Trichoderma is not a common component in non-augmented agricultural soils in the lower Colorado Desert. However, the Trichoderma isolates used in Supresevit and Plantshield colonized the desert soils quite well in most

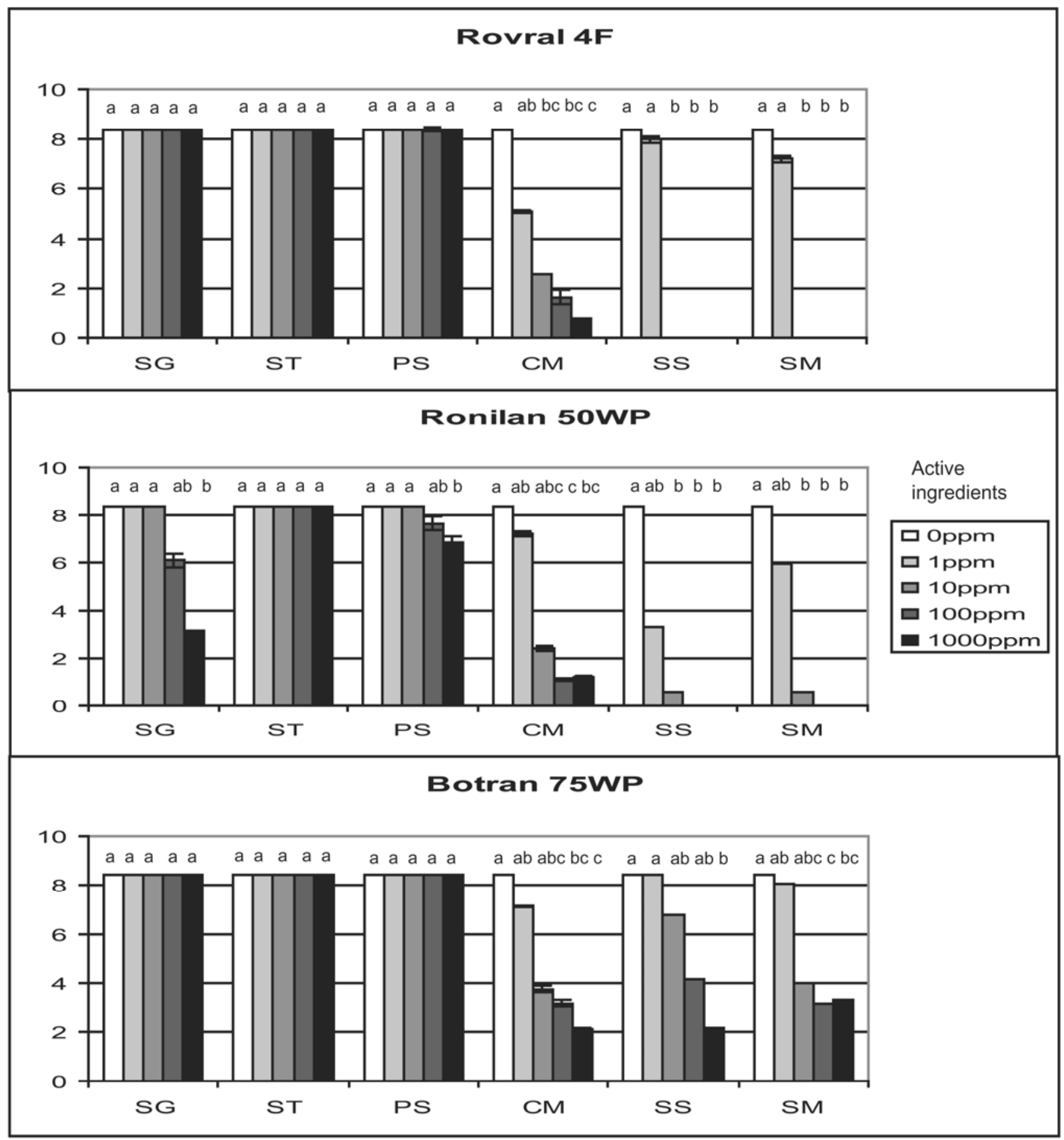

Fig. 4. Influence of different concentration of Rovral, Ronilan, and Botran in potato dextrose agar (PDA)-amended media on mycelial growth of different biocontrol fungi and Sclerotinia spp. in vitro in 2001-2003 experiment. Each value is the mean of three replicates. Columns with different letters are significantly different according to Tukey's test $(P<0.05)$. SG, Gliocladium virens (Soilgard); ST, Trichoderma harzianum (Supresevit); PS, Trichoderma harzianum (Plantshield); CM, Coniothyrium minitans (Contans); SS, Sclerotinia sclerotiorum; SM, S. minor. 
experiments conducted over several years. Despite the ample colonization of treated soils by Trichoderma isolates, the products were not effective in reducing losses to lettuce drop. These seemingly contradictory results suggest that the ability to colonize soil to high levels is not a critical factor in assessing the potential of a biocontrol organism at reducing disease.

Commercially, Rovral has been extensively used to control lettuce drop in both California and Arizona, and most studies revealed that it significantly improved lettuce drop control (37,53). However, field losses due to lettuce drop continue to be significant despite common fungicide use $(35,53)$. Reasons for suboptimal performance by Rovral may be a rapid degradation of the fungicide by soilborne microbes in soils with repeated use of the fungicide (40). Moreover, this degradation is exacerbated by high soil $\mathrm{pH}>6.5$ (58), which is a common condition in desert production areas. Rovral served as standard fungicide in all experiments but did not provide any significant control over lettuce drop, especially that caused by $S$. minor. Newly available fungicides such as boscalid, fenhexamide, fluazinam, and fludioxonil (39) are all labeled to manage lettuce drop caused by both Sclerotinia spp. and could function as alternatives to Rovral in areas where Rovral efficacy has declined. Additional studies are underway to test the efficacy of these fungicides singly or in combination with Rovral, biocontrol agents, and other cultural practices to successfully manage lettuce drop (39).

Trichoderma and Gliocladium isolates in Plantshield, Supresevit, and Soilgard were very tolerant to all the fungicides tested even at higher concentrations in all trials. In contrast, $C$. minitans was sensitive to all three fungicides tested even at very low concentrations ( $1 \mathrm{ppm}$ a.i.). $\mathrm{Li}$ et al. (31) previously determined that $C$. minitans was very sensitive to benomyl and vinclozolin in vitro, and Budge and Whipps (9) measured its sensitivity to iprodione. However, in the soil tray assay, $C$. minitans survived well in the soil despite weekly applications of iprodione at twice their recommended concentrations, and disease suppression was enhanced by a single application of iprodione. These results suggest that the fungicide sensitivity of $C$. minitans in vitro does not necessarily impact the efficacy of $C$. minitans to control lettuce drop in the field. Both $S$. sclerotiorum and S. minor were highly sensitive to all three fungicides, which supports their continued use in desert lettuce production.

In summary, results from this study clearly demonstrate that the commercial formulation Contans containing C. minitans was effective for the control of lettuce drop caused by $S$. sclerotiorum in desert lettuce production systems. No product was consistently effective against $S$. minor, including the fungicide Rovral. This difference in control efficacy highlights the differences between $S$. sclerotiorum and $S$. minor, despite similarities in fungal biology, and suggests that the eventual development of successful management for lettuce drop may require different strategies for each Sclerotinia spp.

\section{ACKNOWLEDGMENTS}

This work was supported in part by the University of Arizona, College of Agriculture and Life Sciences, the Arizona Iceberg Lettuce Research Council, and the California Lettuce Research Board.

\section{LITERATURE CITED}

1. Adams, P. B., and Ayers, W. A. 1979. Ecology of Sclerotinia species. Phytopathology 69:896899.

2. Adams, P. B., and Fravel, D. R. 1990. Economical biological control of Sclerotinia lettuce drop by Sporidesmium sclerotivorum. Phytopathology 80:1120-1124.

3. Askew, D. J., and Laing, M. D. 1993. An adapted selective medium for the quantitative isolation of Trichoderma species. Plant Pathol. 42:686-690.

4. Bennett, A. J., Leifert, C., and Whipps, J. M. 2006. Survival of Coniothyrium minitans associated with sclerotia of Sclerotinia sclerotiorum in soil. Soil Biol. Biochem. 38:164172.

5. Bolton, M. D., Thomma, B. P. J., and Nelson, B. D. 2006. Sclerotinia sclerotiorum (Lib) de Bary: Biology and molecular traits of a cosmopolitan pathogen. Mol. Plant Pathol. 7:1-16.

6. Bremer, E., Huang, H. C., Selinger, L. J., and Davis, J. S. 2000. Competence of Coniothyrium minitans in preventing infection of bean leaves by Sclerotinia sclerotiorum. Plant Pathol. Bull. 9:69-74

7. Budge, S. P., McQuilken, M. P., Fenlon, J. S., and Whipps, J. M. 1995. Use of Coniothyrium minitans and Gliocladium virens for biological control of Sclerotinia sclerotiorum in glasshouse lettuce. Biol. Control 5:513-522.

8. Budge, S. P., and Whipps, J. M. 1991. Glasshouse trials of Coniothyrium minitans and Trichoderma species for the biological control of Sclerotinia sclerotiorum in celery and lettuce. Plant Pathol. 40:59-66.

9. Budge, S. P., and Whipps, J. M. 2001. Potential for integrated control of Sclerotinia sclerotiorum in glasshouse lettuce using Coniothyrium minitans and reduced fungicide application. Phytopathology 91:221-227.

10. California Agricultural Statistics Service. 2006. California Agricultural Statistics. California Department of Food and Agriculture. Online publication.

11. Cassiolato, A. M. R., Baker, R., and Melo, I. S. D. 1997. Action of Trichoderma harzianum mutants on the formation and carpogenic germination of Sclerotinia sclerotiorum sclerotia and lettuce plant survival. Fitopatol. Bras. 22:34-38

12. Castro, B. L. 1995. Antagonism of some isolates of Trichoderma koningii, originating in Colombian soils, against Rosellinia bunodes, Sclerotinia sclerotiorum and Pythium ultimum. Fitopatol. Colomb. 19:7-18.

13. Davet, P., and Martin, C. 1993. Resistance of Sclerotinia minor isolates to cyclic imides in lettuce field soils of Roussillon, France. J. Phytopathol. 138:331-342.

14. Davies, J. M. L. 1991. Sclerotinia on peas: Implications of yield and crop rotation. Ann. Appl. Biol. 27:351-354.

15. Dos Santos, A. F., and Dhingra, O. D. 1982. Pathogenicity of Trichoderma spp. on the sclerotia of Sclerotinia sclerotiorum. Can. J. Bot.
60:472-475.

16. Elad, Y. 2000. Trichoderma harzianum T39 preparation for biocontrol of plant diseases Control of Botrytis cinerea, Sclerotinia sclerotiorum, and Cladosporium fulvum. Biocontrol Sci. Technol. 10:499-507.

17. Fravel, D. R., Boland, G. J., and Kuykendall, L. D. 1997. Use of Sporidesmium sclerotivorum for biocontrol of sclerotial plant pathogens. Pages 37-47 in: Plant Microbe Interaction and Biological Control. CRC Press, Boca Raton, FL.

18. Gerlagh, M., Goossen-van de Geijn, H. M., Fokkema, N. J., and Vereijken, P. F. G. 1999 Long-term biosanitation by application of $\mathrm{Co}$ niothyrium minitans on Sclerotinia sclerotiorum-infected crops. Phytopathology 89:141147.

19. Gerlagh, M., Goossen-van de Geijn, H. M., Hoogland, A. E., and Vereijken, P. F. G. 2003. Quantitative aspects of infection of Sclerotinic sclerotiorum sclerotia by Coniothyrium minitans-timing of application, concentration and quality of conidial suspension of the mycoparasite. Eur. J. Plant Pathol. 109:489-502.

20. Grendene, A., and Marciano, P. 1999. Interaction between Sclerotinia sclerotiorum and $\mathrm{Co}$ niothyrium minitans strains with different aggressiveness. Phytoparasitica 27:1-6.

21. Hao, J. J., and Subbarao, K. V. 2003. Effects of broccoli rotation on lettuce drop caused by Sclerotinia minor and on the population density of sclerotia in soil. Plant Dis. 87:159-166.

22. Hao, J. J., and Subbarao, K. V. 2005. Comparative analyses of lettuce drop epidemics caused by Sclerotinia minor and S. sclerotiorum. Plant Dis. 89:717-725.

23. Huang, H., Erickson, R. S., and Huang, C. 2000. Soil treatment with fungal agents for control of apothecia of Sclerotinia sclerotiorum in bean and pea crops. Plant Pathol. Bull. 9:53-58.

24. Huang, H. C., Bremer, E., Hynes, R. K., and Erickson, R. S. 2000. Foliar application of fungal biocontrol agents for the control of white mold of dry bean caused by Sclerotinia sclerotiorum. Biol. Control 18:270-276.

25. Hubbard, J. C., Subbarao, K. V., and Koike, S. T. 1997. Development and significance of dicarboximide resistance in Sclerotinia minor isolates from commercial lettuce fields in California. Plant Dis. 81:148-153.

26. Inbar, J., Menendez, A., and Chet, I. 1996. Hyphal interaction between Trichoderma harzianum and Sclerotinia sclerotiorum and its role in biological control. Soil Biol. Biochem. 28:757-763.

27. Jones, D., and Watson, D. 1969. Parasitism and lysis by soil fungi of Sclerotinia sclerotiorum (Lib.) de Bary, a phytopathogenic fungus. Nature 224:287-288.

28. Jones, E. E., and Stewart, A. 2000. Selection of mycoparasite of sclerotia of Sclerotinia sclerotiorum isolated from New Zealand soils. N.Z. J. Crop. Hortic. Sci. 28:105-114.

29. Jones, E. E., and Whipps, J. M. 2002. Effect of inoculum rates and sources of Coniothyrium minitans on control of Sclerotinia sclerotiorum disease in glass house lettuce. Eur. J. Plant Pathol. 108:527-538.

30. Koch, E. 1999. Evaluation of commercial products for microbial control of soil-borne plant diseases. Crop Prot. 18:119-125.

31. Li, G. Q., Huang, H. C., and Acharya, S. N. 2002. Sensitivity of Ulocladium atrum, Coniothyrium minitans, and Sclerotinia sclerotiorum to benomyl and vinclozolin. Can. J. Bot. 80:892-898.

32. Li, G. Q., Huang, H. C., Acharya, S. N., and Erickson, R. S. 2005. Effectiveness of Coniothyrium minitans and Trichoderma atroviride in suppression of Sclerotinia blossom blight of alfalfa. Plant Pathol. 54:204-211.

33. Li, G. Q., Wei, S. J., Jiang, D. H., and Huang, 
H. C. 2001. Control of Sclerotinia stem rot of canola by aerial application of Coniothyrium minitans. Page 147 in: Proc. Sclerotinia 2001 XI Int. Sclerotinia Workshop. C. S. Young and K. J. D. Hughes, eds. Central Science Laboratory, York, UK.

34. Lorito, M., Woo, S. L., Duffy, B., Rosenberger, U., and Defago, G. 1998. Advances in understanding the antifungal mechanisms of Trichoderma and new applications for biological control. Bulletin-OILB_SROP. 21:73-80.

35. Martin, C., Davet, P., Vega, D., and Coste, C. 1991. Field effectiveness and biodegradation of cyclic imides in lettuce field soils. Pestic. Sci. 32:427-438.

36. Matheron, M. E., and Matejka, J. C. 1989. Evaluation of new fungicides for the control of leaf drop of lettuce. J. Rio Grande Valley Hortic. Soc. 42:71-74.

37. Matheron, M. E., and Porchas, M. 1996. New fungicides evaluated for control of Sclerotinia leaf drop of lettuce in 1997 and 1998. Vegetable report. College of Agriculture and Life Sciences, University of Arizona, Tucson, AZ.

38. Matheron, M. E., and Porchas, M. 2003. The University of Arizona Cooperative Extension Research Reports: Vegetable crops, 19972003. College of Agriculture and Life Sciences, University of Arizona, Tucson, AZ.

39. Matheron, M. E., and Porchas, M. 2004. Activity of boscalid, fenhexamid, fluazinam, fludioxonil, and vinclozolin on growth of Sclerotinia minor and S. sclerotiorum and development of lettuce drop. Plant Dis. 88:665-668.

40. McLean, K. L., and Stewart, A. 2000. Application strategies for control of onion white rot by fungal antagonists. N.Z. J. Crop Hortic. Sci. 28:115-122.

41. McQuilken, M. P., Budge, S. P., and Whipps, J.
M. 1997. Biological control of Sclerotinia sclerotiorum by film-coating Coniothyrium minitans on to sunflower seed and sclerotia. Plant Pathol. 46:919-929.

42. Mcquilken, M. P., Mitchell, S. J., Budge, S. P., Whipps, J. M., Fenlon, J. S., and Archer, S. A. 1995. Effect of Coniothyrium minitans on sclerotial survival and apothecial production of Sclerotinia sclerotiorum in field-grown oilseed rape. Plant Pathol. 44:883-896.

43. Melzer, M. G., and Boland, G. J. 1994. Epidemiology of lettuce drop caused by Sclerotinia minor. Can. J. Plant Pathol. 16(3):170176.

44. Mueller, D. S., Hartman, G. L., and Pedersen, W. L. 2002. Effect of crop rotation and tillage system on Sclerotinia stem rot on soybean. Can. J. Plant Pathol. 24:450-456.

45. National Agricultural Statistics Service. 2002. U.S. Dep. Agric. U.S. Census of Agriculture. Online publication.

46. Partridge, D. E., Sutton, T. B., Jordan, D. L., Curtis, V. L., and Bailey, J. E. 2006. Management of Sclerotinia blight of peanut with the biological control agent Coniothyrium minitans. Plant Dis. 90:957-963.

47. Phillips, A. J. L. 1986. Factors affecting the parasitic activity of Gliocladium virens on the sclerotia of Sclerotinia sclerotiorum and a note on its host range. J. Phytopathol. 116:212-220.

48. Prasad, R. D., and Rangeswaran, R. 1999 Granular formulation of Trichoderma and Gliocladium spp. in biocontrol of Rhizoctonia solani of chickpea. J. Mycol. Plant Pathol. 29:222-226.

49. Providenti, M. A., Mautner, S. I., Chaudhry, O., Bombardier, M., Scroggins, R., Gregorich, E., and Smith, M. L. 2004. Determining the environmental fate of a filamentous fungus,
Trichoderma reesei, in laboratory-contained intact soil-core microcosms using competitive PCR and viability plating. Can. J. Microbiol. 50:623-631.

50. Purdy, L. H. 1979. Sclerotinia sclerotiorum: History, diseases and symptomology, host range, geographic distribution and impact. Phytopathology 69:875-880.

51. Ridgway, H. J., Rabeendran, N., Eade, K., and Stewart, A. 2001. Application timing of Coniothyrium minitans A69 influences biocontrol of Sclerotinia minor in lettuce. Proc. Conf. Palm erston North, New Zealand. N.Z. Plant Prot. 54:14-16.

52. Stoneman, W. F. 2002. Coniothyrium minitans for practical control of Sclerotinia diseases. (Abstr.) Phytopathology 92:S105.

53. Subbarao, K. V. 1998. Progress toward integrated management of lettuce drop. Plant Dis. 82:1068-1078.

54. Whipps, J. M., and Budge, S. P. 1990. Screening for sclerotial mycoparasites of Sclerotinia sclerotiorum. Mycol. Res. 94:607-612.

55. Wu, B. M., Bhat, R. G., Kabir, Z., and Subbarao, K. V. 2003. Production of apothecia by Sclerotinia sclerotiorum in the Salinas valley. (Abstr.) Phytopathology 93:S131.

56. Wu, B. M., and Subbarao, K. V. 2002. Sclerotial survival of $S$. minor and $S$. sclerotiorum in California. (Abstr.) Phytopathology 92:S88.

57. Yates, I. E., Meredith, F., Smart, W., Bacon, C. W., and Jaworski, A. J. 1999. Trichoderma viride suppresses fumonisin $\mathrm{B} 1$ production by Fusarium moniliforme. J. Food Prot. 62:13261332.

58. Zazzerini, A., and Tosi, C. 1985. Antagonistic activity of fungi isolated from sclerotia of Sclerotinia sclerotiorum. Plant Pathol. 34:415421. 